\title{
IMPLEMENTATION OF A PROBLEM-BASED LEARNING METHODOLOGY TO A CHEMICAL ENGINEERING MASTER COURSE
}

\author{
R. Sánchez-Tovar, R.M. Fernández-Domene, M.J. Muñoz-Portero, J. García- \\ Antón
}

Departamento de Ingeniería Química y Nuclear, Universitat Politècnica de València (SPAIN)

\begin{abstract}
Problem-Based Learning (PBL) is a teaching methodology which uses comprehensive real-world problems to introduce the different concepts of the course to students. In this way, PBL methodology tries to develop, among others, problem-solving abilities, communication skills, critical thinking skills, and, the most important, it can promote life-long learning.

PBL methodology was introduced to design the classes of a corrosion course. Corrosion is a course which belongs to the Master of Chemical Engineering and to the Master of Industrial Security and Environmental of the Universitat Politècnica de Valencia (Spain).

In this study it is explained how PBL methodology was designed to cover all the concepts of the course in order that students could acquire generic, technical and specific competences.

The crucial part to succeed in the implementation of the PBL methodology is the design of the problems. In the study it is detailed how problems were designed and the main difficulties found during the implementation of the methodology in the corrosion course.
\end{abstract}

Keywords: Problem-Based Learning, competence, teaching methodologies.

\section{INTRODUCTION}

The traditional learning methodologies, based on lectures and focused on the figure of the teacher, involve the memorization of concepts by students, whose role in the learning process is to remain seated listening to the lesson, taking notes that subsequently they will have to memorize. These methodologies, which tend to alienate the student from their own learning, are notoriously insufficient to achieve the challenges proposed in the European Higher Education Area (EHEA). In fact, EHEA promotes the use of active teaching methodologies in European universities, developing students' autonomy and promoting their awareness and responsibility [1-3].

Problem-based learning (PBL) is a student-centered learning strategy in which students learn about a given subject through the resolution of real problems (or problems that arise). The teacher adopts a guiding role [1-7]. This methodology places students at the center of the process and makes them responsible for their own learning, from an initial knowledge towards continuous exploration in search of a greater conceptual understanding and more information about the matter in question, also promoting skills such as critical thinking, the ability to solve problems, work in a collaborative group or communicative skills $[1,2,4-6]$. Once the problem has been solved, students must explore it and analyze the information they have, look for new sources of information, identify what they need to learn in order to face up to the problem and solve the problem, through critical thinking and creativity. Finally, they have to explain to the rest of the class the obtained conclusions $[2,6,5,8,9]$. In this way, the PBL, learning methodology is organized from the beginning around the proposed problems, instead of being organized around concepts, principles and theories previously explained to solve problems in class. That is, because the classical way of approaching the problem, has little or nothing to do with real life, since problems do not appear that way in the professional world $[4,8]$.

According to several authors, the problem is the fundamental factor for the succeed of the PBL methodology $[3,5,9,10]$. Regarding to this, preparation of the problem is a critical stage to ensure good results in the activity. Real problems that an engineer will find in its daily work are usually more complex and are not fully defined. Additionally, students are usually interested in the immediate application of the knowledge they acquire in order to solve the problems they find. Therefore, the problems proposed in the PBL strategy must be problems that reflect the reality of the professional field in which the student is expected to work. They must be also problems which attract the attention 
of the students, motivating them to be useful in the learning process, and contributing to the cooperation of all the members of the group [5].

The PBL has been successfully implemented in many universities around the world, in many disciplines [2,3,6,7,10-12]. For the study of metal corrosion, this methodology has been implemented, for example, at the University of Manchester, in the United Kingdom.

Given the central relevance of the problems in the PBL methodology and since there is no a problem database in literature to be used, it is necessary to have publications where problems of different types are collected. Therefore, the objective of this work is to design and implement a specific methodology of PBL for a course of corrosion that is taught in the Master of Chemical Engineering and to the Master of Industrial Security and Environmental of the Universitat Politècnica de Valencia. Problems must cover the competences of the course which are the following:

- This subject should promote the independent learning to students.

- After finishing the course students should identify, analyze and solve corrosion problems.

- With this course students should design and optimize corrosion processes.

- Students should learn how to protect materials against corrosion.

Additionally, students should acquire communicative skills, problem-solving abilities and laboratoryinstrumental skills.

\section{METHODOLOGY}

\subsection{Context of the course}

Corrosion, which is currently taught in two Masters at the Universitat Politècnica de València, consists of 4.5 credits, divided into 2.25 credits of class theory, 0.9 credits of class practice and 1.35 credits of laboratory practices. The objective of this subject is to enable the student to identify the different corrosion processes, know the experimental techniques for their study and know how to apply various protection techniques to specific industrial and scientific problems. Table 1 shows how didactic units are structured together with an identification code to relate them later with the different proposed problems.

\subsection{Design of the PBL methodology for the corrosion course. Proposed Problems}

In the corrosion course, the hours of theory and practice are distributed over 12 weeks (1 day per week, 12 sessions in total), while laboratory practices take place in 5 sessions. The PBL methodology will not be used in all sessions, since there are theoretical and practical topics in which it is better to use another type of methodology. For example, the first class session will focus mostly on explaining the PBL methodology that will be used throughout the course, paying special attention on the existing difference between traditional learning methods centered on the teacher and student-centered learning methods. The PBL will not be used in the general introduction to the phenomenon of corrosion (second session of the class), since it is a class designed to introduce and / or refresh the basic concepts from which students will have to acquire the basic and fundamental knowledge about corrosion. Additionally, in this class, the teacher will provide students with sources from which they can extract information throughout the course (books, articles, scientific databases, internet pages, etc.). Similarly, in the sessions dedicated to the explanation and implementation of the experimental techniques used for the study and analysis of corrosion, the PBL methodology will not be used either. However, some problems will require the use of some experimental techniques to obtain information, as will be explained later. 
Table 1. Didactic units and identification code for the corrosion course.

\begin{tabular}{l|c}
\hline \hline \multicolumn{1}{c|}{ Didactic Unit } & Identification Code \\
\hline 1. Basis of electrochemical corrosion & $\mathrm{A}$ \\
\hline $\begin{array}{l}\text { 1.1. Introduction. Description of the physicochemical } \\
\text { phenomenon. }\end{array}$ & $\mathrm{A} 1$ \\
\hline \begin{tabular}{l} 
1.2. Thermodynamic aspects of corrosion. \\
\hline 1.3. Kinetics of corrosion reactions.
\end{tabular} & $\mathrm{A} 2$ \\
\hline 1.4. Passivity and localized corrosion phenomena. & $\mathrm{A} 4$ \\
\hline 2. Experimental techniques for the study of corrosion. & $\mathrm{B}$ \\
\hline $\begin{array}{l}\text { 2.1. DC techniques: cyclic voltametries, potentiostatic and } \\
\text { galvanostatic tests. }\end{array}$ & $\mathrm{B} 1$ \\
\hline 2.2. Electrochemical impedance spectroscopy. & $\mathrm{B} 2$ \\
\hline 2.3. Electrochemical microscopy. & $\mathrm{B} 3$ \\
\hline $\begin{array}{l}\text { 3. Techniques of protection against corrosion and } \\
\text { design strategies. }\end{array}$ & $\mathrm{C}$ \\
\hline 3.1. Corrosion cells. & $\mathrm{C} 1$ \\
\hline 3.2. Techniques of protection against corrosion & $\mathrm{C} 2$ \\
\hline 3.3. Design strategies. & $\mathrm{C} 3$ \\
\hline 4. Industrial and process applications. & $\mathrm{D}$ \\
\hline
\end{tabular}

The rest of the classes (10 sessions in total) will be used to work on the different PBL problems. Depending on the difficulty of each problem, it may be necessary to use more than one class session for its resolution. The problems proposed in the first sessions will be easier and more similar to the typical problems that can be found at the end of a theoretical chapter. As the course progresses and the students increase their knowledge in the corrosion field, they will acquire more confidence in themselves and the complexity of the problems will increase, as well as its relation with the real world. At the end of the problem, one member of the group will have to present the proposed solution and the results will be discussed in class, with the teacher acting as moderator and guide of the debate.

Then, a general description of all the proposed ABP problems to students in the corrosion course, together with their relationship with the didactic units of Table 1 is shown below. For each proposed problem, students will be provided with: (1) a detailed explanation of the context of the problem; (2) the learning objectives (related to one or several didactic units); (3) additional information, if necessary; (4) some suggestions, depending on the difficulty of the problem. This study also provides a detailed description of one of the problems (Problem 5) where all the information described above is shown.

The main difficulties in the implementation of the PBL methodology were found designing attractive problems according to each didactic unit and, additionally, increasing the degree of complexity. Therefore, the preparation of the problems and their relation to Table 1 was one of the most crucial parts of the project.

Problem 1. One of the aluminum pipes on the main facade of your house is severely damaged and threatens to collapse. Precisely, it is the pipe that was put, as a decoration, a copper rain chain, to replace the downpipe that gave a horrible appearance to the facade. It is also bad luck ... Why has only that pipe been damaged? What can be the reason? How can you prevent something like this from happening again in the future? [Related to: A2, C1, (see Table 1)].

Problem 2. In this activity, students should get into the role of a chemical engineer who has to design a carbon steel structure that will work in contact with a concentrated solution of sulfuric acid (1M). To meet the specifications, students have to determine the thickness of the structure, knowing that the specifications say that its durability should be 30 years. To carry out the design, students will have to find out the corrosion rate of carbon steel in that medium. [Related to: A3, B]. 
Problem 3. In a petrochemical industry, it has been observed that a relatively low-alloy stainless steel tank, used in the kerosene treatment line to remove wastewater, is severely damaged, and the yield of the process has decreased after 12 years of service. In all the internal surface of the tank some points, as "holes", can be observed; some of them up to $15 \mathrm{~mm}$ deep. For the wastewater absorption process, sodium chloride $(\mathrm{NaCl})$ is used as an absorbent in that plant. Since the tank was designed for 25 years, people in charge of the plant have contracted an expert engineer in corrosion to solve the problem. [Related to: A4, C2, C3, D].

Problem 4. The students, as researchers working in a company of specialists in accident reconstruction, are in the scenario of a disaster that has generated numerous injuries in a wood pulp production plant. The accident took place when an austenitic stainless steel pipe was drilled, which transported the "white liquor" to the continuous pulp digester, through an area where a weld bead is clearly visible. The white liquor is a very alkaline solution and its spill has caused very serious burns in several workers of the plant. [Related to: A4, C3, D].

Problem 5. For this case, the students are in the following situation: a chemical engineer who works in a desalination plant for multi-effect distillation has to investigate a case of corrosion that drives mad the responsible of the plant. In all the evaporation chambers, built of welded pieces of carbon steel and stainless steel, corrosion have occurred, forcing them to stop production. The carbon steel parts, which were painted with epoxy resin, are severely damaged in the regions where the paint has failed as a result of the passage of time, while the pieces of stainless steel, which were left unpainted for being more resistant, are intact. [Related to: C1, C2, C3, D].

Problem 6. One of the problems in relation to the use of corrosion inhibitors is their composition, since there are many formulations that are toxic and dangerous to the environment. Therefore, a company which is specialist in surface coatings and corrosion protection techniques has begun an exhaustive research to progressively replace their inhibitors with "green" inhibitors. At the moment they are focused on finding and testing inhibitors for carbon steel and copper. The students, in the role of one of the engineers of that company, will have to look for and test the performance of the selected inhibitors in the laboratory. [Related to: B, C2].

Problem 7. You have found a new job as engineer in a company and by chance, you found plans for a new deposit. In those plans you detected some design failures from the corrosion point of view. You know that if deposits are built that way, sooner rather than later the company will have problems with the customers, so you decided to carry out an alternative design. You must be very convincing if you want your supervisor to take your proposals into account. [Related to: C3].

Problem 8. Students are part of the staff of a company that is responsible for designing and manufacturing heat exchangers. The company has received a millionaire order to manufacture heat exchangers that will be installed in a power plant located on the coast, near a fertilizer manufacturing plant, whose liquid effluents (supposedly treated) are discharged directly into the sea. The students have to select materials for this purpose. [Related to: C3, D].

Problem 9. The Infrastructures Service of the Universitat Politècnica de València asked you to detect, correct and avoid future corrosion problems that affect infrastructures of the university and that involve material losses and can put at risk the safety of the people who are part of the university community. As a student of the corrosion course you have to detect these problems and propose possible solutions. [Related to: C3].

\section{RESULTS}

In this section, an example of a real problem is shown.

\subsection{Context of the problem (Problem 5)}

"Come in, come in, please," says the company's production manager, Daniel Martínez, addressing you.

You enter in the meeting room and, while you walk towards the only chair that is free around the central table, you take a look at the people who are already sit. In addition to Juan Parra, you recognize the person responsible for quality and safety, Laura Pastor, and the person responsible for maintenance, Almudena Pérez. There are two other people, a blond man and a brown woman with curly hair, whose faces you remember having seen in the plant, but you are not able to recall their 
names right now. "Something important must have happened if all these people are in a hurry" you think with a little nervousness, and you feel expectant.

"Well, you're already three" -Daniel begins to say looking at the two people you cannot identify and at yourself. "I have gathered you here to talk about the corrosion detected in the evaporation chambers. You all know that for a long time we have been detecting some problems during the multiple evaporation stage and before the continuous warnings, two days ago we decided to stop the production and inspect the chambers inside. In two words: a disaster".

"A real disaster," says Almudena. You can see the photos on the screen. "Observe that the painted areas had totally destroyed parts ... look here, it is not surprising that we were having so many problems!".

"And what about the unpainted areas?" Asks the woman whose name you cannot remember.

"The unpainted areas were intact," Almudena replies.

"They were stainless steel, if I remember correctly, right? The blond man asks.

"The unpainted parts were made of stainless steel, yes, of AISI 304. The painted parts were made of carbon steel", Daniel replies.

"The problem is that we do not understand what may be the reason that the painted pieces have corroded up to that point. I mean, when the design was made, we knew that carbon steel was very little alloyed and resists very little corrosion if compared with AISI 304 so that, when all the pieces are welded together, we had to protect the carbon steel. After consulting several experts on the subject about what would be the best coating for a carbon steel in our conditions of temperature and salinity, we concluded that we should paint those parts of the chamber with epoxy resin". -Explains Almudena.

"And we also used the one they told us that was the best application method, and all the painted pieces passed the most demanding quality tests..." -Added Laura.

"It is very strange" -the woman says, «Susana, it is called Susana», you remember at last.

"The point is that there are two welded metals, one of them more prone to undergo corrosion than the other, right?" -The man begins.

"Yeah, Jaime. Continue to see if we can find the solution for this problem. We are missing something" - says Juan.

"Then, we protected the most vulnerable areas by applying a coating of an epoxy resin, very resistant to aggressive environments" - Jaime continues - "and then, against all odds, after a few years, you have those same pieces painted corroded and the areas of stainless steel unpainted, intact".

"That's right," Laura says, nodding.

"Well, I do not understand", says Susana.

"At the moment nobody understands it, I am afraid" - Daniel comments - "unless..."

In that instant, all heads are turned towards you. You have not talked during the time and the rest of the people are waiting for you to say something.

"You received a course on corrosion during the Master you did, right?" - Daniel asks - "Could you shed some light on such uncertainty? Could you tell us what happened and how can we avoid it in future?".

\subsection{Learning objectives}

- Understand and apply concepts about corrosion cells to real problems (C1, D).

- Know the limitations of the techniques of protection against corrosion (C2) and develop and apply design strategies to minimize the impact of corrosion (C3).

- Analyze problems in a systematic and orderly way, using the given information as a starting point in the process of problem solving and learning.

- Interpret the available information in a critical way: the most logical ideas, at first, do not have to be the right ones.

- Work effectively as a team. 


\subsection{Additional material}

There is no additional material that has been provided at the beginning of the course, regardless of the queries that are made from Internet pages.

\subsection{Suggestions}

- Identify the corrosive medium and all metals involved in the process.

- Think what the expected behaviour of these metals in the corrosive medium under study should be.

- Specify the type of corrosion that the materials should undergo.

- Take into account the factors that have a significant influence on the type of corrosion identified above.

- Different approaches can be proposed to find solutions to the problem.

\section{CONCLUSIONS}

The PBL methodology is a strategy that can give very good results in a course with a lot of practical application, such as metal corrosion. In addition, students can develop a series of skills and competences that are very useful when they faced up to real problems in their professional and personal environment in future.

At the same time, the development of material to apply the PBL methodology is a formative and continuous process for the teaching staff. In this study, several problems for working in class are presented, as well as a methodology to address each of the problems, in order to support teachers who want to start implementing this type of learning strategy in a course of corrosion.

The crucial part to implement the PBL methodology was to adapt and include the teaching objectives of the course into attractive problems related to the professional reality.

\section{ACKNOWLEDGEMENTS}

Acknowledgements: Authors would like to express their gratitude to the project PIME: Aprendizaje Basado en Problemas para su aplicación en las áreas de Ingeniería Química y de Materiales (Ref. 27) and to the Instituto de Ciencias de la Educación and the Vicerrectorado de Estudios, Calidad y Acreditación from the Universitat Politècnica de Valencia, for their financial and technical support.

\section{REFERENCES}

[1] I. Egido Gálvez, R. Aranda Redruello, R. Cerrillo Martín, A. De la Herrán Gascón, S. De Miguel Badesa, M. Gómez García, R. Hernández Castilla, D. Izuzquiza Gasset, F.J. Murillo Torrecilla, M. Pérez Serrano, R.M. Rodríguez Izquierdo, "El Aprendizaje Basado en Problemas como Innovación Docente en la Universidad: Posibilidades y Limitaciones," Educación y Futuro, vol. 16, pp. 85-100, 2007.

[2] J.J. Solaz-Portolés, V. Sanjosé López, A. Gómez López, "Aprendizaje basado en problemas en la Educación Superior: una metodología necesaria en la formación del profesorado," Didáctica de las Ciencias Experimentales y Sociales, vol. 25, pp. 177-186, 2011.

[3] E. López-Zafra, N. Rodríguez-Espartal, L. Contreras, J.M. Augusto Landa, "Evaluación de una experiencia de Aprendizaje Basado en Problemas (ABP) en estudiantes universitarios," Revista d'Innovació Docent Universitària, vol. 7, pp. 71-80, 2015.

[4] E.M. Bridges, P. Hallinger, "Problem-Based Learning in Leadership Education," New Directions for Teaching and Learning, vol. 68, pp. 53-61, 1996.

[5] P. Morales Bueno, V. Landa Fitzgerald, "Aprendizaje Basado en Problemas," Theoria vol. 13, pp. 145-157, 2004. 
[6] O. Méndez, "Diseño de una guía didáctica para la enseñanza de la química a ingenieros civiles en formación desde el enfoque de aprendizaje basado en problemas (ABP)," Revista Educación en Ingeniería, vol. 10, no. Issue 19, pp. 39-48, 2015.

[7] L. Saenz del Burgo, G. Puras Ochoa, "Aprendizaje inductivo basado en problemas: la vida profesional del graduad@ en Farmacia" in Book Title (E. López-Meneses, D. Cobos Sanchiz, A.H. Martín Padilla, L. Molina-García, A. Jaén Martínez, Eds.), pp. 527-536, Spain: INNOVAGOGÍA 2016. III Congreso Internacional sobre Innovación Pedagógica y Praxis Educativa, 2017.

[8] T.O. Peterson, "So you're thinking of trying problem based learning? Three critical success factors for implementation," Journal of Management Education, vol. 28, no. Issue 5, pp. 630-647, 2004.

[9] J.A. Llorens-Molina, "El aprendizaje basado en problemas como estrategia para el cambio metodológico en los trabajos de laboratorio" Química Nova, vol. 33, no. Issue 4, pp. 994-999, 2010.

[10] J.C. Perrenet, P.A.J. Bouhuijs, J.G.M.M. Smits, "The Suitability of Problem-based Learning for Engineering Education: theory and practice," Teaching in Higher Education, vol. 5, no. issue 3, pp. 345-358, 2000.

[11] K.J. Nasr, B.H. Ramadan, "Impact Assessment of Problem-Based Learning in an Engineering Science Course," Journal of STEM Education, vol. 9, no. Issue 3-4, pp. 16-24, 2008.

[12] I. Agirre, J. Requies, V.L. Barrio, "Design, implementation and evolution of PBL approach based on scientific congress model," Innovative and Creative Education and Technology International Conference (ICETIC 2017). 